\title{
Anti-tumour effects and pharmacokinetic profile of 17-(5'-isoxazolyl)androsta-4,16-dien-3-one (L-39) in mice: an inhibitor of androgen synthesis
}

\author{
IP Nnane*, BJ Long, Y-Z Ling ${ }^{\dagger}$, DN Grigoryev and AM Brodie \\ Department of Pharmacology and Experimental Therapeutics, University of Maryland School of Medicine, Baltimore, MD 21201, USA
}

\begin{abstract}
Summary 17-(5'-Isoxazolyl)androsta-4,16-dien-3-one (L-39), a novel androstene derivative, was synthesized and evaluated in vitro and in

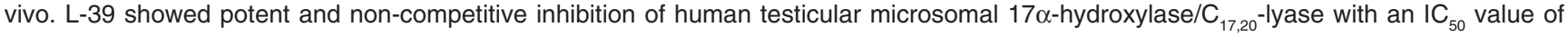
$59 \mathrm{~nm}$ and $K_{\mathrm{i}}$ of $22 \mathrm{nM}$. L-39 also showed potent and competitive inhibition of $5 \alpha$-reductase in human prostatic microsomes with $\mathrm{IC}_{50}$ and $K_{\mathrm{i}}$ values of 33 and $28 \mathrm{~nm}$ respectively. L-39 $(5 \mu \mathrm{M})$ has also been shown to manifest anti-androgenic activity in cultures of human prostate cancer cell lines (LNCaP) by preventing the labelled synthetic androgen R1881 (5 nM) from binding to the androgen receptors. Androgendependent human próstate cancer xenografts (PC-82) were grown in nude mice and the effects of L-39 (50 mg kg-1 day-1) on tumour growth and prostate-specific antigen (PSA) levels were determined after 28 days. L-39 significantly $(P<0.01)$ diminished tumour growth and wet weights to a similar extent as castration or flutamide treatment. L-39 also significantly $(P<0.01)$ reduced serum PSA levels by more than $80 \%$ in the mice bearing human prostate cancer xenografts. Pharmacokinetic studies were also conducted in male Balb/c mice. After subcutaneous administration of a single bolus dose, L-39 was rapidly absorbed into the systemic circulation. Peak plasma levels occurred at $0.75 \mathrm{~h}$ and then declined with a $t_{1 / 2}$ of $1.51 \mathrm{~h}$. The bioavailability of L-39 after subcutaneous administration was $28.5 \%$. These results demonstrate that L-39 is a potent inhibitor of androgen synthesis and is effective in reducing the growth of human prostate cancer xenografts in nude mice. Although improvements in the bioavailability are necessary, L-39 is a potential lead compound with this profile as an inhibitor of prostate cancer growth. (C) 2000 Cancer Research Campaign
\end{abstract}

Keywords: $17 \alpha$-hydroxylase $/ C_{17,20}$-lyase; $5 \alpha$-reductase; androgens; prostate cancer; pharmacokinetics

Prostate cancer is second only to lung cancer as the leading cause of death and is the most prevalent cancer amongst men in the USA and Europe and accounts for about a third of all cancers diagnosed each year in men. In the UK, the incidence of prostate cancer has almost doubled over the last 30 years. Similarly, in 1998, it was estimated that more than 334500 cases were diagnosed and more than 41800 men died of the disease in the USA (Dijkman and Debruyne, 1996). The prostate gland is under the influence of androgens and often becomes enlarged in older men. It has clearly been demonstrated that prostate cancers are androgen-dependent and that withdrawal of androgen supply produced favourable response in patients with adenocarcinoma of the prostate (Saunders, 1963; Rosenberg and Eschenbach, 1990). Localized prostate cancer is curable and although the metastatic form of the disease is difficult to manage, endocrine therapy does reduce the death rate from the disease and is first-line treatment for all patients. In the testis and adrenals, $17 \alpha$-hydroxylase $/ \mathrm{C}_{17,20}$-lyase converts the $\mathrm{C}_{21}$ steroid precursors to the corresponding $\mathrm{C}_{19}$ androgens. Testosterone $(\mathrm{T})$ is further converted to the more potent androgen dihydrotestosterone (DHT) by $5 \alpha$-reductase in the prostate (Bruchovsky and Wilson, 1968). Both T and DHT stimulate prostatic growth, although DHT plays a much more important

Received 9 November 1999

Revised 4 February 2000

Accepted 10 February 2000 role than $\mathrm{T}$ in the organogenesis and homeostasis of the prostate (Wilson, 1996). Current endocrine therapies such as orchidectomy and luteinizing hormone releasing hormone (LHRH) agonists result in reduced androgen production by the testis and are useful in the early stages of prostate cancer. However, these treatment options fail to alter androgen production by the adrenals that may contribute androgen precursors to the prostate. The addition of flutamide, an anti-androgen to inhibit the action of androgens on the prostate, is only partially effective as the disease frequently progresses due to mutations in the androgen receptor, which can utilize flutamide as an agonist. It would appear that total androgen blockade can be therapeutically more effective than conventional androgen ablation therapy (Labrie et al, 1983). However, more effective therapeutic strategies for combating prostate cancer are needed. This may be achieved through dual inhibition of $17 \alpha-$ hydroxylase $/ \mathrm{C}_{17,20}$-lyase and $5 \alpha$-reductase ( $\mathrm{Li}$ et al, 1992; Klus et al, 1996). Several derivatives of oestrogens, progestins and androgens which diminish androgen levels by inhibiting key enzymes in the androgen synthesis cascade have been described (Ayub and Levell 1987; Angelastro et al, 1989; Nakajin et al, 1989; Jarman et al, 1990; Njar and Brodie, 1999). Currently, ketoconazole, an active imidazole fungicide, is the only $17 \alpha-$ hydroxylase/ $\mathrm{C}_{17,20}$-lyase inhibitor that is used clinically to reduce testosterone biosynthesis in the treatment of patients with

*Present address: Department of Pharmaceutical Sciences, Temple University School of Pharmacy, Philadelphia, PA 19140, USA.

$\dagger$ Present address: School of Pharmaceutical Sciences, Beijing Medical University, China. 


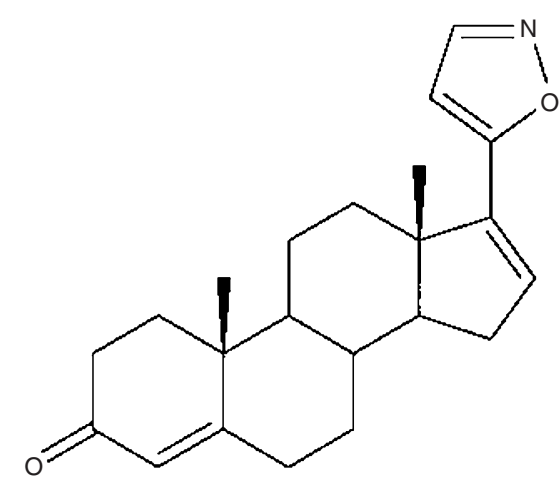

Figure 1 Structure of 17-(5'-isoxazolyl)androsta-4,16-dien-3-one (L-39)

advanced prostate cancer (Small et al, 1997). However, ketoconazole is not very potent and it inhibits several other steroidogenic enzymes and has a number of significant side-effects (Ayub and Levell, 1987; Trachtenberg, 1984). 5 $\alpha$-Reductase occurs in two isoforms namely, type I and type II. The type II isoenzyme is the predominant form in the human prostate. Finasteride, which was recently approved for the treatment of benign prostatic hypertrophy (BPH), is a more potent inhibitor of the type II than the type I isoform (Cunningham and Hirshkowitz, 1995). However, finasteride is only effective against benign prostatic hypertrophy (BPH) in patients with minimal disease and although the compound reduced DHT levels, it also increased serum T levels (Peters and Sorkin, 1993).

We have previously reported the synthesis and testing of several steroidal inhibitors of $17 \alpha$-hydroxylase/ $\mathrm{C}_{17,20}$-lyase and $5 \alpha$-reductase (Li et al, 1995, 1996; Ling et al, 1997; Njar et al, 1998). These compounds were demonstrated to be effective dual inhibitors of human testicular $17 \alpha$-hydroxylase/ $\mathrm{C}_{17,20}$-lyase and prostatic $5 \alpha$-reductase in vitro (Nnane et al, 1998, 1999; Grigoryev et al, 1999). In animal studies, the compounds diminished the levels of circulating $\mathrm{T}$ and DHT in male rat tissues. In LNCaP cell cultures, several of our novel steroidal compounds including 17-(5'-isoxazolyl)androsta-4,16-dien-3-one (L-39; Figure 1) inhibited cellular proliferation and were effective at slowing $\mathrm{LNCaP}$ human prostatic cells grown in male severe combined immunodeficient (SCID) mice as tumours. L-39 (5 $\mu \mathrm{M})$ has also been shown to manifest anti-androgenic activity in cultures of human prostate cancer cell lines (LNCaP) by preventing the labelled synthetic androgen R1881 (5 nM) from binding to the androgen receptors (Long et al, 1999). These compounds, especially L-39, could be more effective than current therapies in the treatment of prostate cancer due to their multiple activities. In the present investigation, we describe the effects of L-39, a novel androstene derivative, in vitro and on human prostate cancer xenografts in nude mice. We also evaluated the pharmacokinetic properties of L-39 in male mice in this investigation.

\section{MATERIALS AND METHODS}

\section{Chemical inhibitors and reagents}

17-(5'-Isoxazolyl)androsta-4,16-dien-3-one (L-39) and its $\Delta^{5}$ hydroxy derivative (L-38) were synthesized in our laboratory according to procedures described previously (Ling et al, 1997). Finasteride was a gift from Merck Research Laboratories
(Rahway, NJ, USA) and ketoconazole was purchased from Sigma Chemical Company (St Louis, MO, USA). [21- $\left.{ }^{3} \mathrm{H}\right]-17 \alpha$-hydroxypregnenolone $\left(13.61 \mu \mathrm{Ci} \mu \mathrm{mol}^{-1}\right)$ was prepared in our laboratory as previously described (Njar et al, 1998). $\left[1,2,6,7-{ }^{3} \mathrm{H}\right]-$ Testosterone $\left(96.5 \mathrm{Ci} \mathrm{mmol}^{-1}\right.$ ) and $\left[4-{ }^{14} \mathrm{C}\right]$-dihydrotestosterone $\left(56.5 \mathrm{mCi} \mathrm{mmol}^{-1}\right)$ were obtained from Dupont (Boston, MA, USA). Silica gel thin layer chromatographic (TLC) plates $(20 \times 20 \mathrm{~cm}$, w/uv 254, 500 microns, GF) were obtained from Analtech (Newark, DE, USA). The active [ $\left.{ }^{125} \mathrm{I}\right]-\mathrm{T}$ coated-tube radioimmunoassay (RIA) kits and the $\left[{ }^{125} \mathrm{I}\right]-\mathrm{DHT}$ coated tube RIA kits for quantitative measurement of $\mathrm{T}$ and DHT, respectively, were purchased from DSL Inc. (Webster, TX, USA). All other reagents were purchased from Sigma Chemical Company (St Louis, MO, USA).

\section{Preparation of microsomes}

Human testes and prostate tissue (from patients with benign prostatic hyperplasia, BPH) were obtained from Dr James Mohler, Director, Urologic Oncology, University of North Carolina at Chapel Hill and stored at $-70^{\circ} \mathrm{C}$ prior to use. Testicular and prostatic microsomes were prepared as described previously (19). Briefly, human testis or prostate was washed with saline $(0.9 \%)$, blotted dry and weighed. The tissue was minced and homogenized in a blender with two volumes of sucrose $(250 \mathrm{~mm})$. The homogenates were added to $50-\mathrm{ml}$ plastic centrifuge tubes and centrifuged at $10000 \mathrm{~g}$ for $30 \mathrm{~min}$. The resulting supernatant was centrifuged at $109000 \mathrm{~g}$ for $1 \mathrm{~h}$ using an ultra-centrifuge. The microsomal pellet was covered with $2 \mathrm{ml}$ of phosphate buffer $(0.1 \mathrm{M})$ and stored at $-70^{\circ} \mathrm{C}$ until required for assay. The microsomal protein content was determined by the Lowry method (Lowry et al, 1951).

\section{$17 \alpha$-hydroxylase/ $C_{17,20}$-lyase activity}

The measurement of the activity of the human $17 \alpha$-hydroxylase/ $\mathrm{C}_{17,20}$-lyase in testicular microsomes, in the absence and presence of inhibitors was performed as described previously ( $\mathrm{Li}$ et al, 1995). Briefly, the $17 \alpha$-hydroxylase/ $C_{17,20}$-lyase activity was determined by measuring the release of $\left[{ }^{3} \mathrm{H}\right]$-acetic acid during the conversion of $\left[21-{ }^{3} \mathrm{H}\right]-17 \alpha$-hydroxypregnenolone to dehydroepiandrosterone. The incubations were carried out in a total volume of $1.01 \mathrm{ml}$. Sample tubes were supplied with $10 \mu \mathrm{l}$ of propylene glycol, $300000 \mathrm{dpm}$ of [21- $\left.{ }^{3} \mathrm{H}\right]-17 \alpha$-hydroxypregnenolone (13.61 $\left.\mu \mathrm{Ci} \mu \mathrm{mol}^{-1}\right)$ and the indicated inhibitors. The control incubations were prepared without the addition of the indicated inhibitors. After evaporation of the ethanolic solution, the following were added to each tube: $750 \mu \mathrm{l}$ of $0.1 \mathrm{M}$ sodium phosphate buffer (pH 7.4, with $78 \mu \mathrm{M}$ of dithiothreitol (DTT)) and $50 \mu \mathrm{l}$ of an NADPH generating system (phosphate buffer containing $6.5 \mathrm{~mm}$ of NADP,$+ 71 \mathrm{~mm}$ of glucose-6-phosphate, 1.25 IU of glucose-6phosphate dehydrogenase). The tubes were pre-incubated for 15 min at $37^{\circ} \mathrm{C}$ and the reaction was started by adding $200 \mu \mathrm{l}$ of human testicular microsomes $(300 \mu \mathrm{g}$ protein per $200 \mu \mathrm{l}$ of phosphate buffer). The reaction tubes were incubated at $37^{\circ} \mathrm{C}$ under oxygen. After $1 \mathrm{~h}$, the tubes were placed in an ice bath and steroids in the reaction mixture were extracted two times with chloroform $(1 \mathrm{ml})$. The tubes were allowed to stand at $4^{\circ} \mathrm{C}$ for $20 \mathrm{~min}$, centrifuged at $4^{\circ} \mathrm{C}$ for $15 \mathrm{~min}$ at $2000 \mathrm{~g}$ and then $0.75 \mathrm{ml}$ of the aqueous phase of each tube was placed into a fresh tube. To remove residual steroids, which may remain after the chloroform 
extraction, $0.75 \mathrm{ml}$ of charcoal solution $(2.5 \mathrm{~g}$ of activated charcoal per $100 \mathrm{ml}$ of distilled water) was added to each tube and mixed vigorously. After standing for $30 \mathrm{~min}$, the charcoal was pelleted by centrifugation at $2000 \mathrm{~g}$ for $20 \mathrm{~min}$. Finally, $0.75 \mathrm{ml}$ of the supernatant was analysed for tritium by liquid scintillation spectrometry. The reaction conditions were optimized with $0.1-6.0 \mu \mathrm{M}$ of $\left[21-{ }^{3} \mathrm{H}\right]-17 \alpha$-hydroxypregnenolone and the $K_{\mathrm{m}}$ and $V_{\max }$ values were determined at the optimum conditions. The optimum conditions were microsomal protein content of $300 \mu \mathrm{g}$ protein per incubation, a substrate concentration of $0.48 \mu \mathrm{M}$, an incubation time of $1 \mathrm{~h}$ and a $\mathrm{pH}$ of 7.4. The $\mathrm{IC}_{50}$ values for inhibitors were calculated using linear regression analysis and the plot of log of enzyme activity against log of inhibitor concentration. The $K_{\mathrm{i}}$ values were also determined at the same reaction conditions with addition of appropriate concentrations of inhibitors. $K_{\mathrm{i}}$ values were calculated from a graph of the slopes of the Lineweaver-Burke plots versus L-39 concentration using the equation of the regression lines. The experiments were performed in duplicate and repeated at least twice (i.e. $n \geq 3$ ).

\section{$5 \alpha$-Reductase assay}

The effects of novel compounds on human prostatic $5 \alpha$-reductase activity were evaluated as previously described ( $\mathrm{Li}$ et al, 1992) with some modifications. Ethanolic solutions of $\left[1,2,6,7-{ }^{3} \mathrm{H}\right] \mathrm{T}$ (600 $000 \mathrm{dpm})$, cold $\mathrm{T}(4.8 \mathrm{ng})$, indicated inhibitors $(0-200 \mathrm{nM})$ and propylene glycol $(10 \mu \mathrm{l})$ were added to duplicate sample tubes. The control incubations were prepared without the addition of the indicated inhibitors. The ethanol was evaporated to dryness under a gentle stream of air. The samples were reconstituted in phosphate buffer $(0.1 \mathrm{M}, \mathrm{pH} 7.4,400 \mu \mathrm{l})$ containing DTT $(78 \mu \mathrm{M})$ and the NADPH generating system (NADP, 6.5 mM; glucose-6phosphate, $71 \mathrm{~mm}$; glucose-6-phosphate dehydrogenase, $2.5 \mathrm{IU}$, in $100 \mu \mathrm{l}$ of phosphate buffer) was added to each tube. The tubes were pre-incubated at $37^{\circ} \mathrm{C}$ for $15 \mathrm{~min}$. The enzymatic reactions were initiated by addition of human BPH microsomes (about 180 $\mu \mathrm{g}$ of microsomal protein in $500 \mu \mathrm{l}$ of phosphate buffer) in a total volume of $1.01 \mathrm{ml}$. The incubations were performed for $10 \mathrm{~min}$ under oxygen in a shaking water bath at $37^{\circ} \mathrm{C}$. The incubations were terminated by placing the sample tubes on ice. $\left[4-{ }^{14} \mathrm{C}\right]-\mathrm{DHT}$ $(3000 \mathrm{dpm})$ and cold DHT $(50 \mu \mathrm{g})$ were added to each tube as an internal standard and visualization marker respectively. These additions were immediately followed by ether $(1 \mathrm{ml})$. The steroids were extracted with ether $(3 \times 1 \mathrm{ml})$, separated by TLC (chloroform:ether, 80:20) and visualized by exposure to iodine vapour. The TLC spot corresponding to DHT was scraped, extracted with ether and analysed for ${ }^{3} \mathrm{H}$ and ${ }^{14} \mathrm{C}$ using a liquid scintillation counter. The percentage conversion of $\left[1,2,6,7-{ }^{3} \mathrm{H}\right] \mathrm{T}$ to $[1,2,6,7-$ ${ }^{3} \mathrm{H}$ ]DHT was calculated and used to determine $5 \alpha$-reductase activity. The reaction conditions were optimized with $\mathrm{T}(0-60 \mathrm{nM})$ and the $K_{\mathrm{m}}$ and $V_{\max }$ values were estimated at the optimum conditions. The optimum conditions were microsomal protein content of $180 \mu \mathrm{g}$ protein per incubation, a substrate concentration of $40 \mathrm{nM}$, an incubation time of $10 \mathrm{~min}$ and $\mathrm{a} \mathrm{pH}$ of 7.4. The $\mathrm{IC}_{50}$ values were determined from log-log plots of $5 \alpha$-reductase activity against four different concentrations of the inhibitor. The $K_{\mathrm{i}}$ values were also determined at the same reaction conditions with addition of appropriate concentrations of inhibitors. $K_{\mathrm{i}}$ values were calculated from a graph of the slopes from the Lineweaver-Burke plots versus L-39 concentration using the equation of the regression line. The experiments were performed in duplicate and repeated at least twice (i.e. $n \geq 3$ ).

\section{Human PC-82 prostate cancer xenograft model}

Male athymic Ncr-nu mice ( 20 g) obtained from NCI (Frederick, $\mathrm{MD}$, USA) were maintained under sterile conditions in a controlled environment of about $25^{\circ} \mathrm{C}, 50 \%$ relative humidity and $12 \mathrm{~h}$ of light and $12 \mathrm{~h}$ of dark cycles and allowed free access to food and water. The experiments were performed in accordance with guidelines approved by the Veterinary Resources Unit of the University of Maryland School of Medicine, Baltimore. PC-82 tumour was originally kindly provided by Dr John Isaacs (John Hopkins University). The PC-82 tumour (1000 mg) was minced in pieces of $1-2 \mathrm{~mm}^{3}$, suspended in Matrigel $(10 \mathrm{ml})$ and an aliquot $(0.1 \mathrm{ml})$ transplanted with a Trocar needle (18 gauge) into both right and left flanks of 5-6 weeks old male athymic Ncr-nu mice. The tumour volumes in each mouse were determined weekly using calipers and allowed to reach $300 \mathrm{~mm}^{3}$ before treatment. Tumour volumes were calculated using the following formula: tumour volume $=0.5236 \times r_{1}^{2} \times r_{2}\left(r_{1}<r_{2}\right)$, where $r_{1}$ and $r_{2}$ are radius measurements from tumours. The animals were randomized into treatment groups of 6-8 and administered vehicle (control), flutamide and L-39. The compounds $\left(10 \mathrm{mg} \mathrm{ml}^{-1}\right)$ were dissolved in $40 \%$ aqueous $\beta$-cyclodextrin and administered subcutaneously, on the rear dorsal area of the animal, at a dose level of $50 \mathrm{mg} \mathrm{kg}^{-1}$ ( $100 \mu \mathrm{l}$ of drug formulation) daily for 28 consecutive days. A group of mice (6-8) was castrated and injected with the vehicle alone for 28 days. The animals were weighed and tumour volumes measured weekly. The mice were sacrified at the end of the treatment period (1-2 $\mathrm{h}$ after the last administered dose) and tumours harvested. The tumours were cleaned, weighed and stored at $-70^{\circ} \mathrm{C}$ until analysis. Blood samples were also collected, centrifuged to obtain serum and stored at $-70^{\circ} \mathrm{C}$ until required.

\section{Testosterone RIA}

Serum and tumour tissues obtained from individual male mice were thawed and homogenized in phosphate buffer $(\mathrm{pH} 7.4,0.1$ $\mathrm{M})$. The homogenates were centrifuged at $2000 \mathrm{~g}$ for $20 \mathrm{~min}$. Serum $(50 \mu \mathrm{l})$ and aliquots $(50 \mu \mathrm{l})$ of the tissue supernatant were used to determine $\mathrm{T}$ concentration as described in the ${ }^{125} \mathrm{I}-\mathrm{T}$ assay kit supplied by DSL Inc. Radioactivity was measured using a Packard Cobra II gamma counter.

\section{DHT RIA}

Serum and tumour tissues obtained from individual male mice were thawed and homogenized in phosphate buffer ( $\mathrm{pH} 7.4,0.1$ M). Serum $(0.4 \mathrm{ml})$ and aliquots $(0.4 \mathrm{ml})$ of the tumour supernatant were extracted with $4 \mathrm{ml}$ of hexane:ethanol $(98: 2)$ mixture. The extracts were dried under a gentle stream of air, dissolved in sample diluent and used for the determination of DHT concentrations as described in the ${ }^{125} \mathrm{I}-\mathrm{DHT}$ assay kit. Radioactivity was measured using a Packard Cobra II gamma counter.

\section{PSA ELISA}

Serum and tumour tissues obtained from individual mice were thawed and homogenized in phosphate buffer ( $\mathrm{pH} 7.4,0.1 \mathrm{M})$. The homogenates were centrifuged at $2000 \mathrm{~g}$ for $20 \mathrm{~min}$. Serum and 

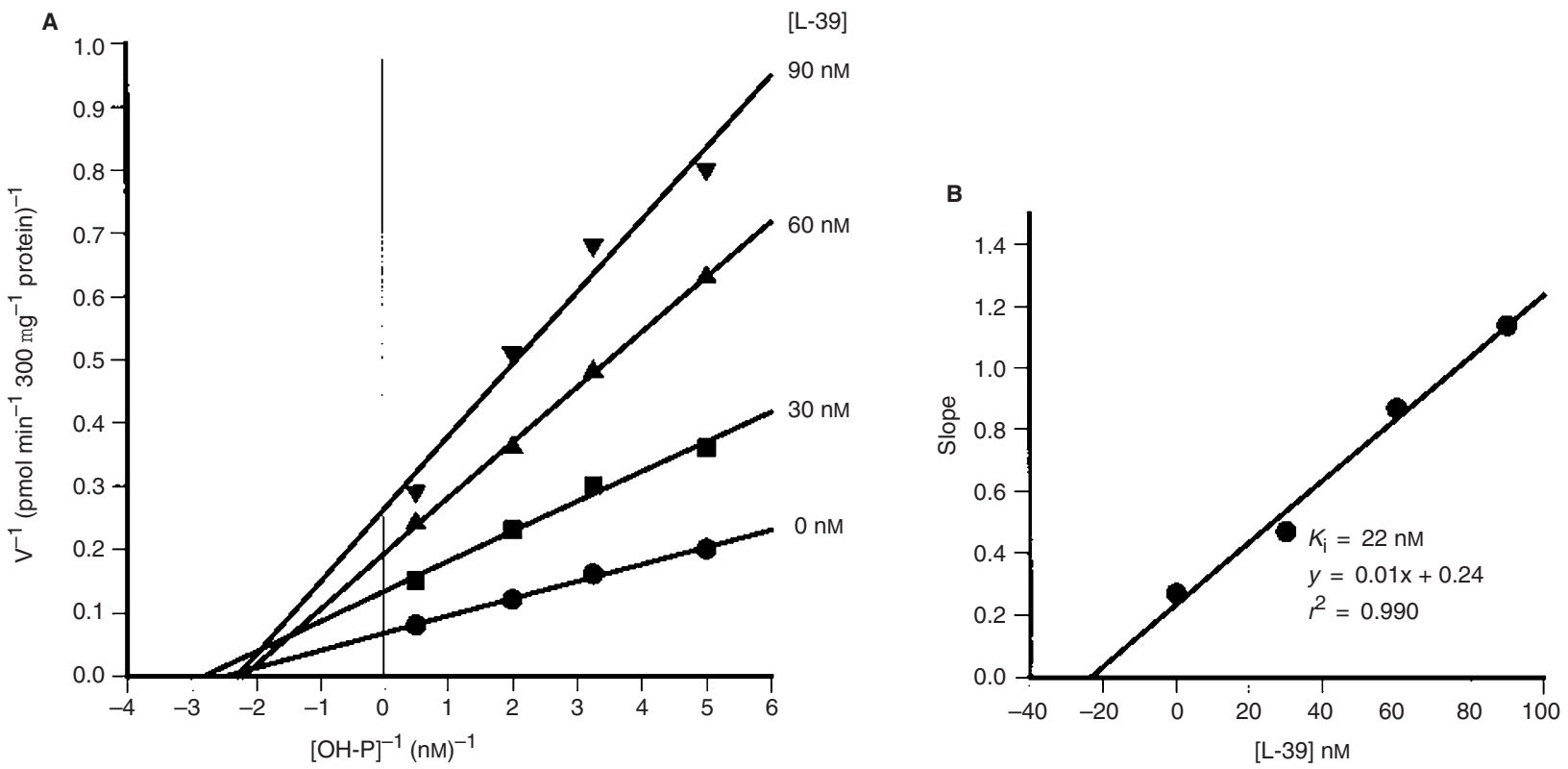

Figure 2 Inhibition of human testicular microsomal $17 \alpha$-hydroxylase/ $\mathrm{C}_{1720}$-lyase by L-39. (A) Lineweaver-Burk plot of enzyme activities at various substrate and inhibitor concentrations, (B) slopes of each reciprocal plot against L-39 concentration. Human testicular microsomes were prepared and

$17 \alpha$-hydroxylase/ $C_{17,20}$-lyase activity determined as described in Materials and Methods. The $K_{\mathrm{m}}$ and $V_{\max }$ values for $17 \alpha$-hydroxylase/ $\mathrm{C}_{17.20^{-}}$-lyase, under the optimum incubation conditions were $0.48 \mu \mathrm{M}$ and $40 \mathrm{pmole} \mathrm{mg}^{-1}$ protein $\mathrm{min}^{-1}$. Each point is the mean of duplicate determination of at least three separate experiments. $\mathrm{OH}-\mathrm{P}=17 \alpha$-hydroxypregnenolone. The standard deviations (not shown) were $5-8 \%$ of mean values. $r \geq 0.995$

aliquots of the tissue supernatant were diluted 1:10 in phosphate buffer $(\mathrm{pH} 7.4,0.1 \mathrm{M})$ and $25 \mu \mathrm{l}$ used for the determination of PSA concentrations as described in the PSA enzyme-linked immunosorbent assay (ELISA) kit supplied by DSL Inc. The absorbance was measured at $450 \mathrm{~nm}$ using a Dynatech MRX plate reader.

\section{Pharmacokinetic studies}

Male Balb/c mice (8-10 weeks old) obtained from NCI (Frederick, MD, USA) were maintained in a controlled environment of about $25^{\circ} \mathrm{C}, 50 \%$ relative humidity and $12 \mathrm{~h}$ of light and $12 \mathrm{~h}$ of dark cycles and allowed free access to food and water. L-39 and flutamide were formulated in $40 \% \beta$-cyclodextrin in water and a single subcutaneous or intravenous bolus dose was given to mice. The animals were sacrificed at various times up to $24 \mathrm{~h}$ after drug administration and blood was obtained by cardiac puncture under light fluothane (Ayerst, New York, NY, USA) anaesthesia.

\section{HPLC analysis}

The high-performance liquid chromatographic (HPLC) system consisted of a Waters ${ }^{\circledR}$ solvent delivery system, Waters 600 controller (Milford, MA, USA) coupled to Waters ${ }^{\circledR} 717^{\text {plus }}$ autosampler and a Water ${ }^{\circledR} 996$ photodiode array detector operated at $254 \mathrm{~nm}$. Chromatographic separation and quantitation of L-39 and the internal standard, L-38, was achieved by reversed phase HPLC on a Water ${ }^{\circledR}$ Novapak $^{\circledR}$ C18 column $(3.9 \times 150 \mathrm{~mm})$ protected by a Waters ${ }^{\circledR}$ guard cartridge packed with pellicular C18. The mobile phase composition was water/methanol/ acetonitrile/acetic acid (25:50:25:0.0001, v/v) and was pumped at a flow rate of $1.0 \mathrm{ml} \mathrm{min}{ }^{-1}$. The HPLC analysis was performed at ambient temperature and data acquisition and management was achieved with a Waters ${ }^{\circledR}$ millennium chromatography manager.

\section{Sample preparation}

L-39 and its $\Delta^{5}$ hydroxy derivative, L-38, were made up to $1 \mathrm{mg}$ $\mathrm{ml}^{-1}$ in ethanol and stored in the fridge $\left(4^{\circ} \mathrm{C}\right)$ until required. From these stock solutions, dilutions of 1,10 and $100 \mu \mathrm{g} \mathrm{ml}^{-1}$ in ethanol were prepared for use in construction of calibration curves. For sample preparation, test-tubes containing plasma $(250 \mu \mathrm{l}), \mathrm{L}-39$ and the internal standard, L-38 $\left(10 \mu \mathrm{g} \mathrm{ml} \mathrm{ml}^{-1}, 6.25 \mu \mathrm{l}\right)$, were extracted with diethyl ether $(2 \times 2 \mathrm{ml})$ using a vortex mixer for $1 \mathrm{~min}$ and centrifugation at $1500 \mathrm{~g}$ for $5 \mathrm{~min}$. The organic layers were evaporated to dryness under a gentle stream of air. The extracts were reconstituted in acetonitrile $(250 \mu \mathrm{l})$ and loaded into a solid phase Sep-Pak 1cc C18 cartridge (Waters, Milford, MA, USA) pre-washed with methanol $(1 \mathrm{ml})$ for further purification. The cartridge was then eluted with acetonitrile $(250 \mu \mathrm{l})$, the eluate evaporated to dryness and the residue reconstituted in mobile phase $(50 \mu \mathrm{l})$ and filtered using $0.2 \mu \mathrm{m}$ teflon filters for HPLC analysis.

\section{Calibration curves and HPLC assay validation}

The calibration curves for L-39 were constructed by spiking varying amounts of L-39 $\left(0-1\right.$ or $0-10 \mu \mathrm{g} \mathrm{ml}^{-1}$ ranges $)$ and the internal standard, L-38 $\left(6.25 \mu \mathrm{l}\right.$ of $10 \mu \mathrm{g} \mathrm{ml} \mathrm{m}^{-1}$ or $6.25 \mu \mathrm{l}$ of $100 \mu \mathrm{g} \mathrm{ml}^{-1}$ respectively) into extraction tubes containing blood $(0.25 \mathrm{ml})$ from untreated animals. The calibration samples were taken through the extraction procedure as described above. An aliquot of the reconstituted extract $(10 \mu \mathrm{l})$ was injected onto the HPLC column and the ratio of the peak area for L-39 to that of the internal standard (L-38) were plotted against concentrations of L-39. The analytical procedure was validated by determining the 
[L-39]
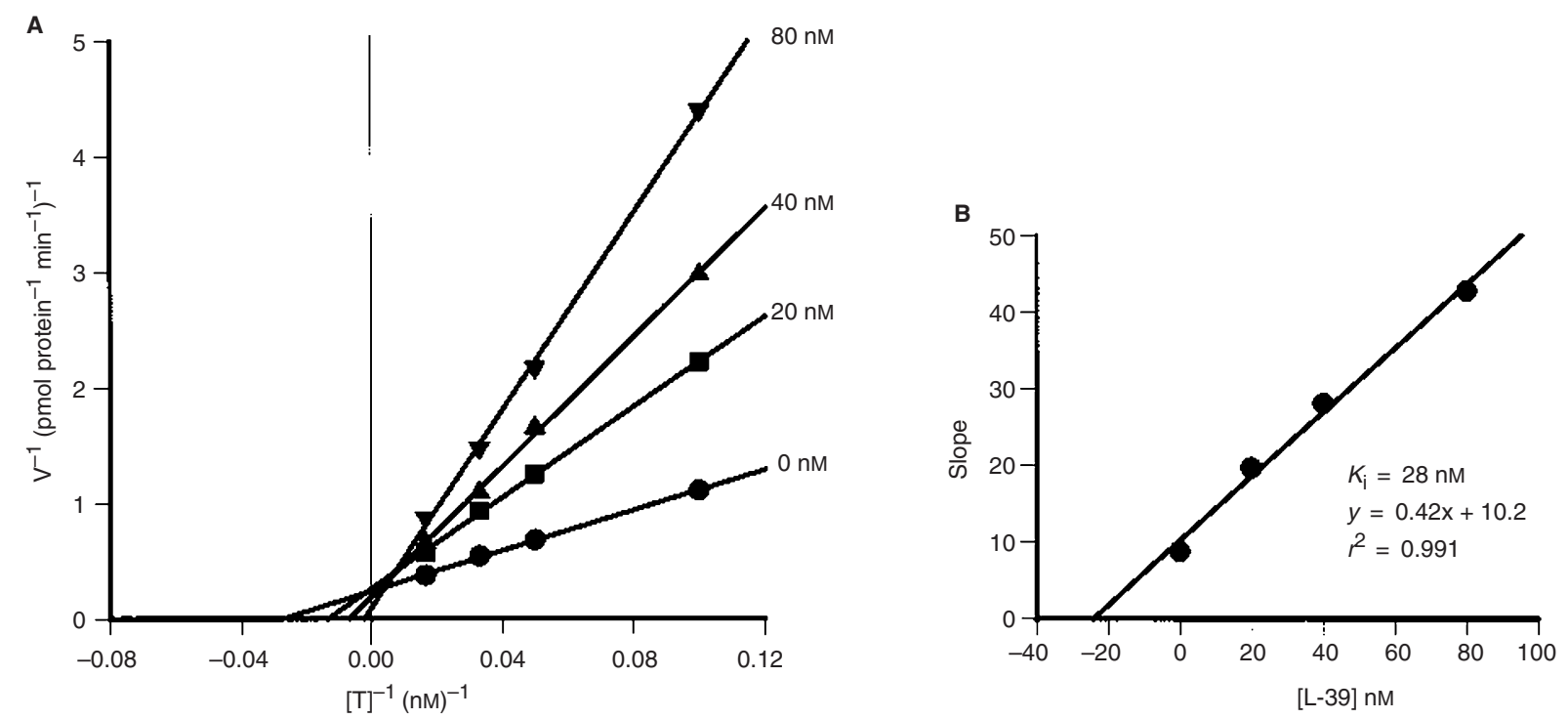

Figure 3 Inhibition of human prostatic microsomal $5 \alpha$-reductase by L-39. (A) Lineweaver-Burk plot of enzyme activity at various substrate and inhibitor concentrations, (B) Slopes of each reciprocal plot against L-39 concentration. Human prostatic microsomes were prepared and $5 \alpha$-reductase activity determined as described in Materials and Methods. The $K_{m}$ and $V_{\text {max }}$ values for $5 \alpha$-reductase, under the optimum incubation conditions were $40 \mathrm{~nm}$ and $2 \mathrm{pmole} \mathrm{mg}^{-1}$ protein $\mathrm{min}^{-1}$. Each point is the mean of duplicate determination of at least three separate experiments. The standard deviations (not shown) were $3-7 \%$ of mean values. $r \geq 0.995$

precision and accuracy of the method. The precision and accuracy of the assay was determined by spiking known concentrations of L-39 into sample tubes containing control plasma and taken through the extraction procedure. The study was repeated on three separate occasions and the coefficient of variation $(\mathrm{CV})$, a measure of precision, and the mean percentage difference, $\operatorname{MD}(\%)$, a measure of accuracy, were calculated.

\section{Statistical analysis}

Non-compartmental pharmacokinetic calculations were performed using WinNonlin (Scientific consulting Inc.) One-way analysis of variance (ANOVA) on SigmaStat for Windows version 1.0 was used to compare different treatment groups at the $95 \%$ confidence level. The Bonferroni post-hoc test was used for determination of significance. A $P$-value of less than 0.05 was considered as statistically significant.

\section{RESULTS}

The $K_{\mathrm{m}}$ and $V_{\max }$ values for $17 \alpha$-hydroxylase $/ \mathrm{C}_{17,20}$-lyase were $480 \mathrm{~nm}$ and 40 pmole $\mathrm{mg}^{-1}$ protein $\mathrm{min}^{-1}$ respectively, and the reaction was linear with time for up to $1 \mathrm{~h}$ of incubation. L-39 showed potent and non-competitive inhibition of human testicular microsomal $17 \alpha$-hydroxylase/ $\mathrm{C}_{17,20}$-lyase with an $\mathrm{IC}_{50}$ value of $59 \mathrm{nM}$ and $K_{\mathrm{i}}$ of $22 \mathrm{nM}$ (Figure 2). In comparison, ketoconazole, a known competitive inhibitor of $17 \alpha$-hydroxylase $/ \mathrm{C}_{17,20}$-lyase, had an $\mathrm{IC}_{50}$ value of $78 \mathrm{~nm}$ and $K_{\mathrm{i}}$ of $38 \mathrm{~nm}$. L-39 also showed potent and competitive inhibition of $5 \alpha$-reductase in human prostatic microsomes with $\mathrm{IC}_{50}$ and $K_{\mathrm{i}}$ values of 33 and $28 \mathrm{~nm}$ respectively (Figure 3). In comparison, finasteride, a clinically available inhibitor of $5 \alpha$-reductase had an $\mathrm{IC}_{50}$ value of $33 \mathrm{nM}$ and $K_{\mathrm{i}}$ of $36 \mathrm{~nm}$. The $K_{\mathrm{m}}$ and $V_{\max }$ values for $5 \alpha$-reductase were $40 \mathrm{~nm}$ and 2 pmole $\mathrm{mg}^{-1}$ protein $\mathrm{min}^{-1}$ respectively, and the reaction was linear with time for up to $20 \mathrm{~min}$ of incubation.

Administration of L-39 (50 mg kg-1 daily, subcutaneously, for 28 days) to male athymic mice bearing PC-82 tumours significantly reduced tumour volumes and weights compared to controls (Figure 4). The volume of PC-82 prostate cancer xenografts in athymic male nude mice increased by twofold over 28 days in the control group. In comparison, the percentage increase in tumour volume in mice treated with L-39 over 28 days was 1.25 -fold. L-39 also significantly diminished PC-82 tumour weights by $70 \%$ (Figure 4). The potency of L-39 was similar to that of flutamide in reducing the growth of human PC82 prostate tumour xenografts in nude mice. Gross examination of vital organs such as the liver, kidney and heart and the adrenal gland did not reveal toxicity. Furthermore, the weight of these organs and the body weight of the animals did not change significantly following treatment with L$39\left(50 \mathrm{mg} \mathrm{kg}^{-1}\right)$. Data from other studies in our laboratory show that maximum suppression of serum testosterone and DHT is achieved by the $50 \mathrm{mg} \mathrm{kg}^{-1}$ dose of L-39. Hence, the $50 \mathrm{mg} \mathrm{kg}^{-1}$ dose was used in the tumour studies since increasing the dose further did not result in a proportional decrease in serum androgen levels. Furthermore, the $50 \mathrm{mg} \mathrm{kg}^{-1}$ dose was used in the tumour studies because no difference in the plasma concentrations of L-39 was seen between the 50 and $100 \mathrm{mg} \mathrm{kg}^{-1}$ dose in the pharmacokinetic studies (Figure 5).

L-39 significantly $(P<0.05)$ reduced T and DHT concentrations in PC-82 tumour xenografts by $64 \%$ and $94 \%$ respectively, although it failed to alter serum androgen levels to any significant extent. L-39 also reduced $(P<0.01)$ serum and tumour PSA levels by $80 \%$ and $50 \%$ respectively, and to about the same extent as castration and flutamide treatment in mice bearing human prostate cancer xenografts (Figure 6).

On reversed phase HPLC, L-39 was well resolved from the internal standard (L-38) and other endogenous compounds in mouse plasma (Figure 7). The calibration curves derived for L-39 

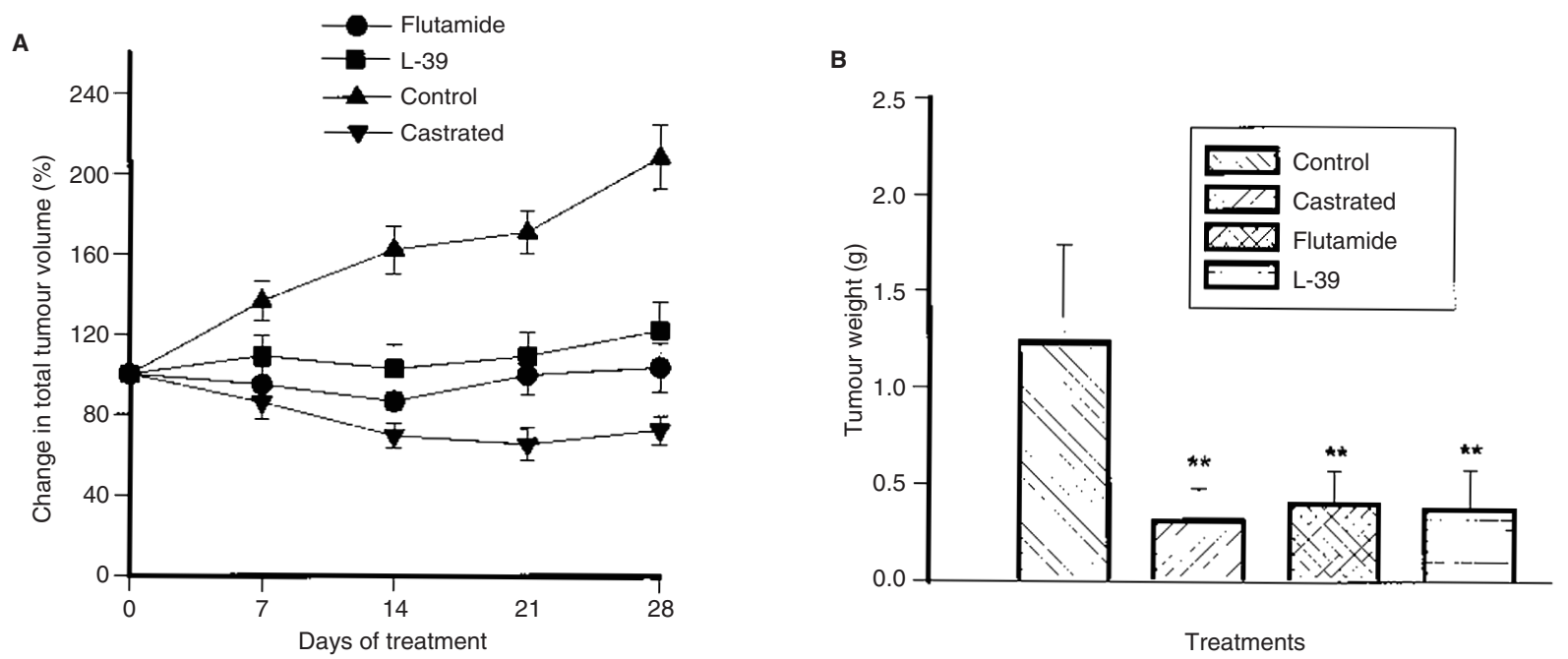

Figure 4 The effect of L-39 and other endocrine therapies on the growth of human prostate cancer xenografts in male athymic nude mice. (A) Tumour volumes, (B) tumour weights. Male athymic mice ( 20 g) were treated with the compounds listed (50 mg kg day $^{-1}$, s.c., for 28 consecutive days). Tumour volumes were measured weekly. The animals were sacrificed after 28 days and the tumours harvested and weighed. Values are the means \pm standard error from 6-8 mice. ${ }^{\star} P<0.05$, and ${ }^{\star *} P<0.01$, compared to the control group

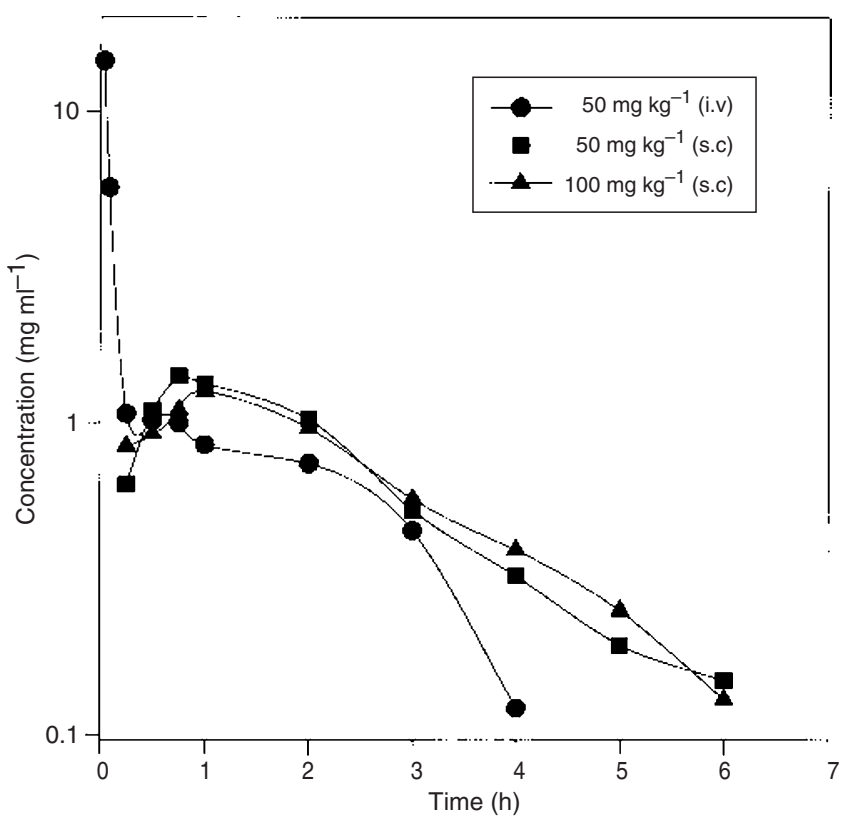

Figure 5 Pharmacokinetics profile of L-39 following administration of a single subcutaneous or intravenous bolus dose to male mice. Male Balb/c mice $(\sim 20 \mathrm{~g})$ were injected with L-39 (50 and $\left.100 \mathrm{mg} \mathrm{kg}^{-1}\right)$ as a single bolus dose and blood collected at predetermined time points. The samples were analysed as described in Materials and Methods. Each data point represents the mean of plasma concentrations obtained from at least three mice. The standard deviations (not shown) were $\pm 3-7 \%$ of the mean values

were linear and reproducible (data not shown) and the inter- and intra-assay variability was less than $10 \%$. The limit of detection for L-39 in mouse plasma was $0.05 \mu \mathrm{g} \mathrm{ml}^{-1}$. The HPLC assay was validated and used to monitor L-39 concentrations in mice plasma. The typical mean plasma concentration-time profiles of L-39 after administration of a single bolus dose of $50 \mathrm{mg} \mathrm{kg}^{-1}$, intravenously or subcutaneously, to male mice are shown in Figure 5. Following intravenous administration, the plasma concentration of L-39 declined exponentially with a mean half-life of $0.66 \mathrm{~h}$ and a
Table 1 Pharmacokinetic parameters of L-39 in mice following a single intravenous or subcutaneous bolus dose

\begin{tabular}{|c|c|c|c|}
\hline \multirow[t]{2}{*}{ Parameter } & \multicolumn{2}{|c|}{ Subcutaneous } & \multirow{2}{*}{$\begin{array}{r}\text { Intravenous } \\
50 \mathrm{mg} \mathrm{kg}^{-1}\end{array}$} \\
\hline & $50 \mathrm{mg} \mathrm{kg}^{-1}$ & $100 \mathrm{mg} \mathrm{kg}^{-1}$ & \\
\hline$K_{\mathrm{el}}\left(\mathrm{h}^{-1}\right)$ & $0.46 \pm 0.02$ & $0.53 \pm 0.03$ & $1.05 \pm 0.05$ \\
\hline$T_{1 / 2>}(\mathrm{h})$ & $1.51 \pm 0.08$ & $1.31 \pm 0.06$ & $0.66 \pm 0.04$ \\
\hline $\left.\mathrm{AUC}_{0-\infty} \mu \mathrm{g} \mathrm{ml}^{-1} \cdot \mathrm{h}^{-1}\right)$ & $4.09 \pm 0.16$ & $4.04 \pm 0.20$ & $14.41 \pm 0.56$ \\
\hline $\mathrm{Cl}\left(\mathrm{I} \mathrm{h}^{-1} \mathrm{~kg}^{-1}\right)$ & $12.24 \pm 0.48$ & $24.78 \pm 1.0$ & $3.47 \pm 0.14$ \\
\hline$V_{d}\left(\mathrm{~kg}^{-1}\right)$ & $26.73 \pm 1.04$ & $46.80 \pm 1.84$ & $3.30 \pm 0.13$ \\
\hline MTR (h) & $2.52 \pm 0.11$ & $2.41 \pm 0.10$ & $1.15 \pm 0.05$ \\
\hline$T_{\max }(\mathrm{h})$ & $0.75 \pm 0.0$ & $1.0 \pm 0.0$ & - \\
\hline$C_{\max }\left(\mu \mathrm{g} \mathrm{ml}^{-1}\right)$ & $1.42 \pm 0.05$ & $1.30 \pm 0.04$ & - \\
\hline
\end{tabular}

Male mice $(25 \pm 5 \mathrm{~g})$ were injected with L-39 (50 or $100 \mathrm{mg} \mathrm{kg}^{-1}$, s.c. or

$50 \mathrm{mg} \mathrm{kg}^{-1}$ i.v). The animals were sacrificed and blood collected at predetermined time points. plasma concentrations of L-39 were determined by HPLC, as described in Materials and Methods. Values represent the means \pm standard deviations from at least three mice.

terminal elimination rate constant of $1.052 \mathrm{~h}^{-1}$. L-39 was rapidly cleared (total clearance of $3.51 \mathrm{~h}^{-1} \mathrm{~kg}^{-1}$ ) from the systemic circulation and was not detectable $4 \mathrm{~h}$ after administration. The calculated non-compartmental pharmacokinetic parameters based on the plasma concentration profile following intravenous administration of L-39 are shown on Table 1. L-39 was detected in mice plasma from 5 min to $6 \mathrm{~h}$ following subcutaneous administration of a $50 \mathrm{mg} \mathrm{kg}^{-1}$ dose. The blood levels of L-39 peaked at about $0.75 \mathrm{~h}$ and then declined exponentially (Figure 5) with a mean half-life of $1.51 \mathrm{~h}$ and a terminal elimination rate constant of 0.46 per h. The bioavailability following subcutaneous administration of L-39 (50 mg kg-1) was $28.5 \%$. The calculated noncompartmental pharmacokinetic parameters based on the plasma concentration profile following subcutaneous administration of L-39 are shown on Table 1. The terminal slope of the plasma concentration-time profile of L-39 following subcutaneous administration is shallower compared to the terminal slope following intravenous dosing. Thus, the pharmacokinetic study indicates that 
A

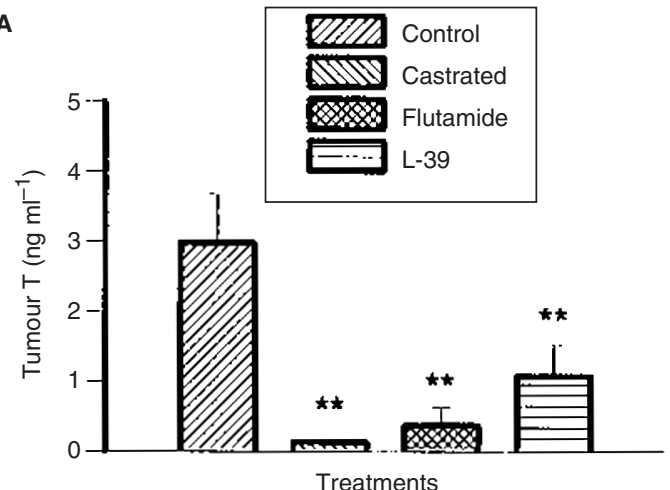

B

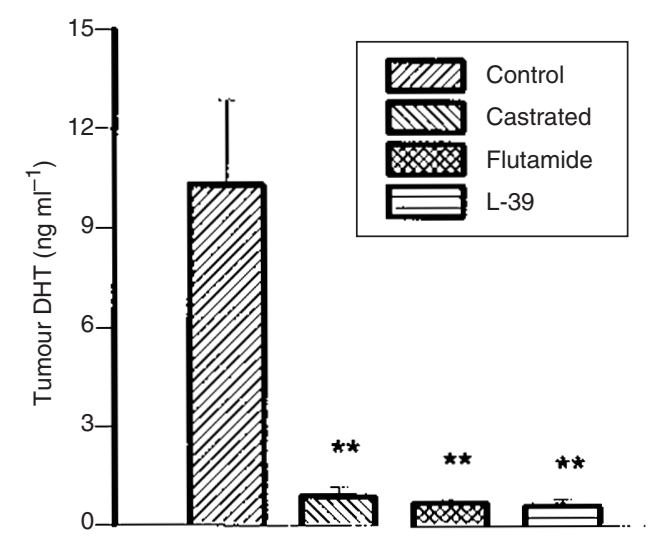

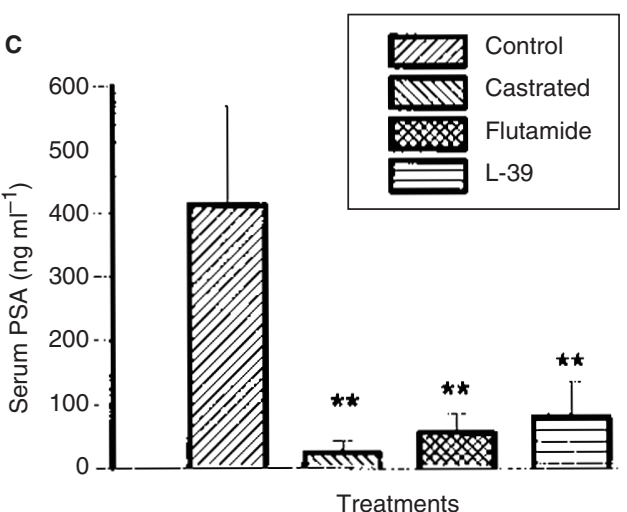

D

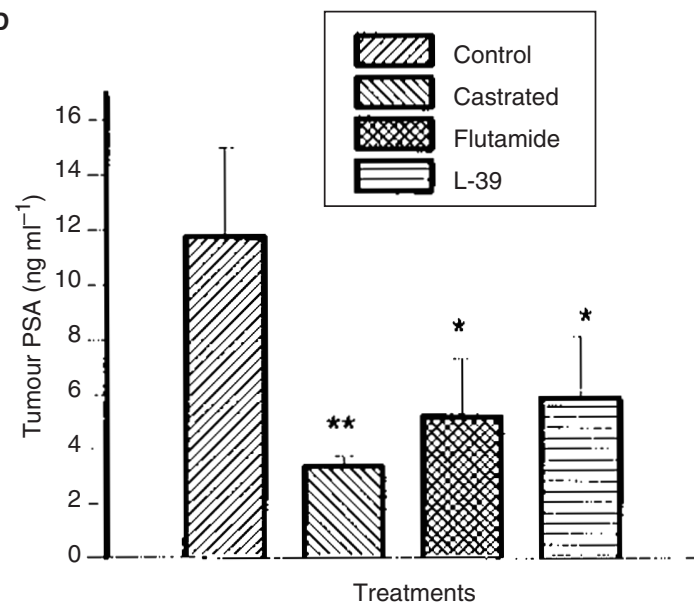

Figure 6 Effects of L-39 on (A) tumour T, (B) tumour DHT, (C) serum PSA and (D) tumour PSA levels in athymic nude mice. Male athymic mice ( 20 g) were treated with the compounds listed $\left(50 \mathrm{mg} \mathrm{kg}^{-1}\right.$ day ${ }^{-1}$, s.c., for 28 consecutive days). The animals were sacrificed after 28 days and blood was collected and tumours harvested. Serum and tumor concentrations of testosterone (T), dihydrotestosterone (DHT) and PSA were determined by RIA and ELISA as described under Materials and Methods. Values represent the means \pm standard error from $6-8$ mice. ${ }^{*} P<0.05$, and ${ }^{* *} P<0.01$, compared to the control group

L-39 persists in the blood longer when administered subcutaneously. When a higher dose of L-39 (100 mg kg-1) was administered subcutaneously to male mice, the plasma concentration versus time curve was almost superimposable on the plasma concentration versus time curve for the $50 \mathrm{mg} \mathrm{kg}^{-1}$ following subcutaneous administration of L-39. Hence, the area under the plasma concentration-time profile did not change significantly after subcutaneous administration of the higher dose (Table 1). However, the volume of distribution and the total clearance were increased significantly at the higher dose.

\section{DISCUSSION}

$17 \alpha$-hydroxylase/ $\mathrm{C}_{17,20}$-lyase catalyses the early step in the biosynthesis of $\mathrm{T}$ and other androgens in both the testes and the adrenal glands, while $5 \alpha$-reductase converts $\mathrm{T}$ to DHT in the prostate gland (Saunders, 1963). Both T and its metabolite, DHT, promote prostatic growth and cancer. Thus, inhibition of both enzymes would be expected to result in diminished levels of circulating $\mathrm{T}$ and DHT and therefore serve as a useful strategy for developing new treatments for prostate cancer (Nnane et al, 1998, 1999). Several inhibitors of $17 \alpha$-hydroxylase/ $\mathrm{C}_{17,20}$-lyase and/or $5 \alpha$ reductase have been described previously, however, they have a number of limitations. Ketoconazole, currently used in the treatment of prostate cancer, is an inhibitor of several P450 enzymes including $17 \alpha$-hydroxylase/C $C_{17,20}$-lyase (Small et al, 1997), and causes side-effects such as nausea, dry skin, asthenia, etc. (Trachtenberg, 1984). Finasteride, an inhibitor of $5 \alpha$-reductase, induces accumulation of $\mathrm{T}$ (Peters and Sorkin, 1993) and has no activity against $17 \alpha$-hydroxylase/ $\mathrm{C}_{17.20}$-lyase (Nnane et al, 1998). L-39 is a dual inhibitor of $17 \alpha$-hydroxylase/ $\mathrm{C}_{17,20}$-lyase and $5 \alpha$-reductase. L-39 showed non-competitive inhibition and probably binds strongly to the apoprotein of $17 \alpha$-hydroxylase/ $\mathrm{C}_{17,20^{-}}$ lyase (Figure 2). L-39 was a potent competitive inhibitor of $5 \alpha$-reductase. The observed anti-tumour effects of L-39 are therefore due to its potent inhibition of androgen synthesis, at least in part. L-39 $(5 \mu \mathrm{M})$ has also been shown to manifest anti-androgenic activity in cultures of human prostate cancer cell lines (LNCaP) by preventing the labelled synthetic androgen R1881 (5 nM) from binding to the androgen receptors (Long et al, 1999). The interaction of L-39 with the androgen receptor together with its potent inhibition of androgen synthesis makes L-39 a promising lead compound for the treatment of prostate cancer.

Furthermore, L-39 was effective in vivo in reducing tumour volumes and weights and PSA and androgen levels in tumour tissues. These effects were produced without a significant change 


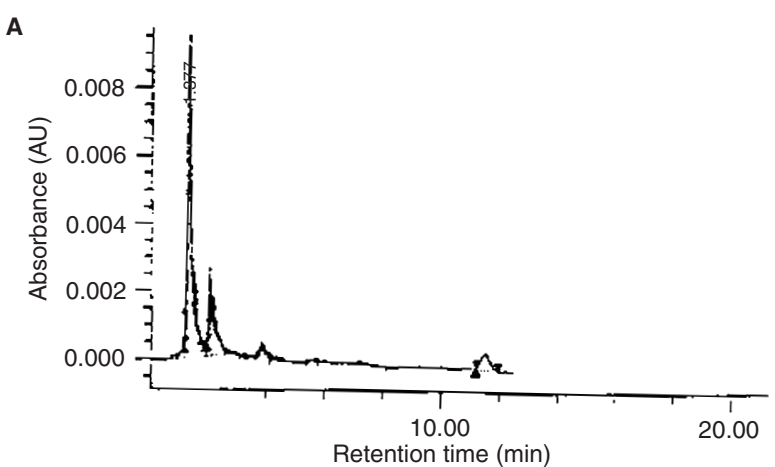

B

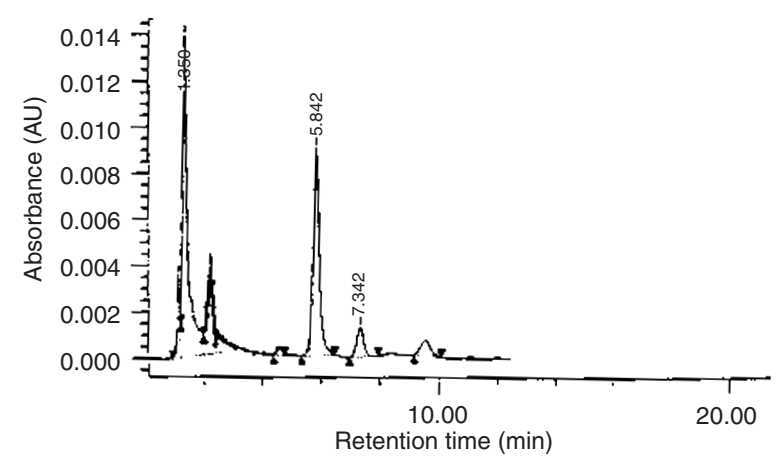

C

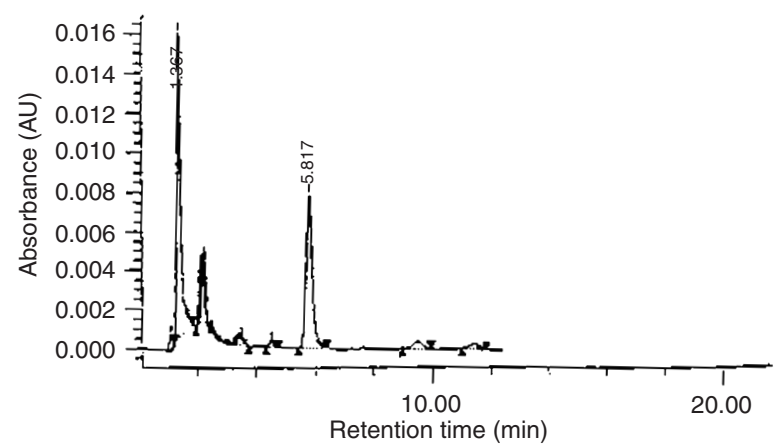

Figure 7 Typical HPLC chromatogram of L-39 and L-38 (internal standard) extrated from mouse plasma. (A) untreated mouse plasma, (B) untreated mouse plasma spiked with L-39 and L-38, (C) plasma sample from mouse treated with L-39. The retention times for L-39 and the internal standard L-38 were 5.8 and 7.3 min respectively

the weights of vital organs and the body weight of the animals following treatment with L-39 $\left(50 \mathrm{mg} \mathrm{kg}^{-1}\right)$, an indication that the compound is well tolerated by the animals.

Surgical castration is the traditional approach to lower androgen levels in vivo and was used in this investigation as the standard for comparison. This novel steroid was as effective as castration and flutamide in reducing androgen concentration and PSA levels in tumour tissues. Flutamide, an anti-androgen, is currently used clinically in combination with LHRH analogue, leuprolide (Crawford et al, 1989). However, the duration of its effect is often limited by the development of androgen receptor mutants that respond to flutamide as an agonist. Tumour growth and weight are regulated by both T and DHT, albeit to a greater extent by the latter (Wilson, 1996). Thus, the significant reduction in the levels of androgens by L-39 may explain the corresponding reduction in tumour volume and weight observed after treatment of nude mice bearing PC-82 tumors with L-39. The serum marker, PSA, has been used to determine the status of prostate cancer in patients and is a valid end point for assessing progression of the disease (Roach, 1996). Our novel androstene derivative, L-39, was effective in lowering PSA levels $(P<0.001)$ in mice bearing human PC-82 tumours and its effectiveness was similar to that of castration $(P>0.05)$. Other studies in our laboratory indicate that L-39 inhibits proliferation $\mathrm{LNCaP}$ human prostate cancer cells in culture and is effective at slowing $\mathrm{LNCaP}$ human prostatic cells grown in male SCID mice as tumours (Long et al, 1999). This finding suggests that L-39 may also be effective in treating tumours with the mutated androgen receptor.

Our results indicate that although L-39 is a potent inhibitor of androgen synthesis in vitro and is effective in reducing serum and tumour androgen concentrations, its effectiveness in vivo on $\mathrm{T}$ levels is weaker than that of castration. The half-life of L-39 was about $1.51 \mathrm{~h}$ after subcutaneous administration. The relatively short half-life of the compound may explain its efficacy in vivo since it was less than expected based on its in vitro potency. It may be necessary to administer L-39 more frequently or increase its bioavailability in order to increase efficacy in vivo. Although the in vivo activity of L-39 was less than expected, the observed antitumour effect suggests that the initial concentrations of L-39 in circulation may be sufficiently high for the compound to irreversibly bind and saturate the $17 \alpha$-hydroxylase/ $\mathrm{C}_{17,20}$-lyase. In fact, other steroidal compounds with a 16-17 double bond have been shown to be irreversible inhibitors of $17 \alpha$-hydroxylase/ $\mathrm{C}_{17,20^{-}}$ lyase (Jarman et al, 1990). The pharmacokinetics study indicate that L-39 persists in the blood slightly longer when administered subcutaneously. This persistence may be due to slower release of L-39 into the systemic circulation from the subcutaneous depot and may be a more useful method of administration for achieving levels that inhibit the enzyme and bind androgen receptors in the tumour. The relatively low bioavailability $(28.5 \%)$ of the compound may also be limiting its efficacy in vivo. The area under the curve did not increase proportionately with an increase in the dose of L-39 following subcutaneous administration. It would appear, therefore, that L-39 exhibits non-linear pharmacokinetics. This observation suggests that the processes of uptake, distribution and metabolism of L-39 are saturable and that the doses used are sufficiently high to cause saturation of these processes. Initial observations in our laboratory indicate that L-39 is metabolized to a more polar metabolite in mice although the metabolite has not yet been characterized. Moreover, L-39 is poorly soluble in water and was formulated in $40 \%$ aqueous $\beta$-cyclodextrin. Although a homogeneous solution was obtained with $40 \%$ aqueous $\beta$ cyclodextrin, L-39 may precipitate at the site of injection. This may affect the rate and extent of L-39 that is systemically available and that may explain, at least in part, the observed non-linear kinetics of L-39. The relatively large volume of distribution suggests that L-39 may be extensively bound to plasma proteins or is distributed extensively within the extravascular tissues. Studies on the uptake and distribution of the compound into the testis and tumours and on protein binding are in progress. Studies are also in progress to improve the formulation of L-39 such that adequate levels of the drug are maintained in the systemic circulation for a longer period of time in order to increase it efficacy in vivo.

In conclusion, the findings in this investigation indicate that L-39 is a potent inhibitor of androgen synthesis and is also effective in reducing the growth of human PC-82 tumours in nude mice. Recent studies in our laboratory have also shown that L-39 manifests anti-androgenic activity in vitro and that it blocked the 
mutated androgen receptor in LNCaP cells. Thus, the compound was more effective than flutamide in mice with $\mathrm{LNCaP}$ tumours (Long et al, 1999). Although inhibition of androgen synthesis appear to be the primary mode of action of L-39, the overall antitumour effect, due to its other mechanisms of action, may be of benefit in treating prostate cancer. In fact, the ability of L-39 to interact with the androgen receptor may also contribute significantly to the observed anti-tumour activity in vivo. Although improvements in the formulation and pharmacokinetic profile are necessary, L-39 is a promising lead compound for the treatment of hormone-dependent cancer of the prostate.

\section{ACKNOWLEDGEMENTS}

This work was supported by NIH grant No. CA-27440 and funds from Paramont capital Inc.

\section{REFERENCES}

Angelastro MR, Laughlin ME, Schatzman GL, Bey P and Blohm TR (1989) 17 $\alpha-$ (cyclopropylamino)-androsta-5-en- $3 \alpha$-ol, a selective mechanism based inhibitor of cytochrome $\mathrm{P}-450_{17 \alpha}$ (steroid $17 \alpha$-hydroxylase $/ \mathrm{C}_{17,20}$ lyase). Biochem Biophys Res Commun 162: 1571-1577

Ayub M and Levell MJ (1987) Inhibition of testicular 17 $\alpha$-hydroxylase and 17,20lyase but not 3-hydroxysteroid dehydrogenase-isomerase or 17-hydroxysteroid oxidoreductase by ketoconazole and other imidazole drugs. J Steroid Biochem 28: 521-531

Bruchovsky N and Wilson JD (1968) The conversion of testosterone to $5 \alpha$-androsta$17 \alpha$-ol-3-one by rat prostate in vivo and in vitro. J Biol Chem 243: 2012-2021

Crawford ED, Eisenberger MA, McLeod DG, Spaulding JT, Benson R, Dorr FA, Blumenstein BA, Davies MA and Goodman PJ (1989) A controlled trial of leuprolide with and without flutamide in prostatic carcinoma. N Engl J Med 321: $419-424$

Cunningham GR and Hirshkowitz M (1995) Inhibition of steroid 5 $\alpha$-reductase with finasteride: sleep-related erections, potency and libido in healthy men. J Clin Endocrinol Metab 80: 1934-1940

Dijkman GA and Debruyne FM (1996) Epidemiology of prostate cancer. Eur Urol 30: 281-295

Grigoryev DN, Long BJ, Nnane IP, Njar VCO, Liu Y and Brodie AMH (1999) Effects of new $17 \alpha$-hydroxylase/ $\mathrm{C}_{17,20}$-lyase inhibitors on $\mathrm{LNCaP}$ prostate cancer cell growth in vitro and in vivo. Br J Cancer. 81: 622-630

Jarman M, Barrie SE, Deadman JJ, Houghton J and McCague R (1990) Novel inhibitors of enzymes of androgen biosynthesis. J Med Chem 33: 3050-3055

Klus GT, Nakamura J, Li J, Ling Y, Son C, Kemppainen JA, Wilson EM and Brodie AMH (1996) Growth inhibition of human prostate cells in vitro by novel inhibitors of androgen synthesis. Cancer Res 56: 4956-4964

Labrie F, Dupont A, Belanger A, Lacoursiere Y, Raynaud JP, Husson JM, Gareau J, Fazekas ATA, Sandow J, Monfette G, Girard JG, Emond J and Houle JG (1983) New approach in the treatment of prostate cancer: complete instead of partial withdrawal of androgens. Prostate 4: 579-594
Li J, Li Y, Son C, Banks P and Brodie A (1992) 4-Pregnen-3-one-20 $\alpha$ carboxyaldehyde: a potent inhibitor of $17 \alpha$-hydroxylase $/ \mathrm{C}_{17,20}$ lyase and of 5o-reductase. J Steroid Biochem Mol Biol, 42: 313-321

Li J, Li Y, Son C and Brodie AMH (1995) Inhibition of androgen synthesis by 22-hydroximino-23, 24-bisnor-4-cholen-3-one. Prostate 26: 140-150

Li JS, Li Y, Son C and Brodie A (1996) Synthesis and evaluation of pregnane derivatives as inhibitors of human testicular $17 \alpha$-hydroxylase/ $\mathrm{C}_{17,20}$ lyase. J Med Chem 39: 4335-4339

Ling Y, Li J, Liu Y, Kato K, Klus GT and Brodie A (1997) 17-Imidazolyl, pyrazolyl and isoxazolyl androsteine derivatives. Novel steroidal inhibitors of human cytochrome $\mathrm{C}_{17,20}$-lyase (P-450 ${ }_{17 \alpha}$ ). J Med Chem 40: 3297-3304

Long BJ, Grigoryev DN, Nnane IP, Liu Y, Ling Y, Wang X and Brodie A (1999) In vitro and in vivo inhibition of LNCaP prostate cancer cell growth by novel inhibitors of androgen synthesis. In: Proceedings of the 90th Annual Meeting of American Association for Cancer Research, Philadelphia, 1999, vol. 40, p 64 (abstract).

Lowry OH, Roseborough NS, Farr AL and Randall RS (1951) Protein measurement with the folin phenol reagent. J Biol Chem 193: 265-275

Nakajin S, Takahashi K and Shinoda M (1989) Inhibitory effects and interaction of stanozolol with pig testicular cytochrome P-450 ( $17 \alpha$-hydroxylase/ $\mathrm{C}_{17,20}$ lyase). Chem Pharm Bull 7: 1855-1858

Njar VCO and Brodie AMH (1999) Inhibitor of $17 \alpha$-hydroxylase/C ${ }_{17,20}$ lyase (CYP17): potential agents for the treatment of prostate cancer. Current Pharm Design 5: 163-180

Njar VCO, Kato K, Nnane IP, Grigoryev DN, Long BJ and Brodie AMH (1988) Novel azolyl steroids; potent inhibitors of human cytochrome $17 \alpha$ hydroxylase $/ \mathrm{C}_{17,20}$-lyase $\left(\mathrm{P}-450_{17 \alpha}\right)$ : potent inhibitors for the treatment of prostate cancer. J Med Chem 41: 902-912

Nnane IP, Kato K, Liu Y, Lu Q, Wang X, Ling Y and Brodie A (1998) Effects of some novel inhibitors of $\mathrm{C}_{17,20}$-lyase and $5 \alpha$-reductase in vitro and in vivo and their potential role in the treatment of prostate cancer. Cancer Res $\mathbf{5 8}$ 3826-3832

Nnane IP, Kato K, Liu Y, Long BJ, Lu Q, Wang X, Ling Y and Brodie A (1999) Inhibition of androgen synthesis in human testicular and prostatic microsomes and in male rats by novel steroidal compounds. Endocrinology 140: 2891-2897

Peters DH and Sorkin M (1993) Finasteride: a review of its potential in the treatment of benign prostatic hyperplasia. Drugs 46: 177-208

Roach M (1996) The role of PSA in the radiotherapy of prostate cancer. Oncology 10: $1143-1153$

Rosenberg AG and von Eschenbach AC (1990) Hormonal therapy for prostate cancer. Semin Surg Oncol 6: 71-76

Saunders FJ (1963) Some aspects of relation of structure of steroids to their prostate stimulating effects. In: Prostate and Related Tissues (National Cancer Institute monograph No 12), Vollmer EP (ed), pp. 139-159. US Government Printing Office: Washington, DC

Small EJ, Baron AD, Fippin L and Apodaca D (1997) Ketoconazole retains activity in advanced prostate cancer patients with progression despite flutamide withdrawal. J Urol 157: 204-1207

Trachtenberg J (1984) Ketoconazole therapy in advanced prostatic cancer. J Urol 132: $61-63$

Wilson JD (1996) Role of dihydrotestosterone in androgen action. Prostate 6: $88-92$ 